\title{
MORPHOLOGICAL DESCRIPTION OF LARVAE OF THE MAPARÁ HYPOPHTHALMUS EDENTATUS (SPIX) (OSTEICHTHYES, HYPOPHTHALMIDAE) IN THE ITAIPU RESERVOIR (PARANÁ RIVER, BRAZIL)
}

\author{
Keshiyu Nakatani ${ }^{1}$ \\ Gilmar Baumgartner ${ }^{1}$ \\ João Dirço Latini ${ }^{1}$
}

\begin{abstract}
The ontogenetic aspects of larvae of Hypophthalmus edentatus (Spix, 1829) from the ichthyoplankton samples collected in the Itaipu reservoir between March 1988 and April 1990 were analysed. Sample were caught by $0.5 \mathrm{~mm}$ mesh conic-cylindrical plankton net. Larvae of $H$. edentatus were identified and described as Siluriforms from the morphological and morphometric development series. They have a small to medium-sized head, long body, small eyes, little pigmentation, mandibular barbules and 53 to 56 myomeres. High values obtained with correlation coefficient $(r>0.97 ; p<0.001)$ show that growth was proportional in different parts of the body.

KEY WORDS. Hypophthalmus edentatus, fish larvae, Itaipu reservoir, larval development, Paraná River
\end{abstract}

The first studies about development of fish eggs and larvae in Brazil were conducted by VON IHERING (1934), who successfully developed the induced oviposition technique (WOYNAROVICH \& HOVATH 1980). Although these studies began more than 60 years ago, little is known about freshwater ichthyoplankton, since only $2 \%$ of Cypriniformes and Characiformes larvae have been identified (RICHARDS 1985).

In the upper River Paraná basin, studies on the biology and ecology of fish larvae are scarce. Studies are restricted to preliminary surveys of eggs and larvae of the floodplain and Itaipu reservoir (FUEM/ITAIPU BINACIONAL 1990; NAKATANI $e t$ al. 1993).

The family Hypophthalmidae are commercially explored fish in the Itaipu reservoir. According to AGOSTINHO et al. (1994), the mapará juveniles are restricted to the reservoir, marginal lakes of the floodplain and adjacent sites close to these environments. RINGUELET et al. (1967) characterize adults of Hypophthalmus edentatus (Spix, 1829) by a high head at the posterior region, compressed body, eyes in ventro-lateral position, mental barbules next to the mandibular symphysis, tender and uniformly colored skin in the dorsal part with no blotches, and silvery at

1) Departamento de Biologia, Nupélia, Universidade Estadual de Maringá. Avenida Colombo 5790, 87020-900 Maringá, Paraná, Brazil. 
the sides. According to J.C. Oliveira (personal communication) the most evident diagnostic characteristics are the shape of the caudal fin and the relatively large size of the pectoral fins. Characteristics of fins are: dorsal fin with: I+6; pectoral: I+14-17; ventral: $1+5$; anal: $\mathrm{v}+54-66$; caudal: $8+9$; branchiostegal rays: $13-15$; gill rakers of first branchial arch: $12+1+117-29+1+197$ and undifferentiated vertebrae: 50-56.

The aim of this research work is to contribute to the knowledge of the morphology of Hypophthalmus edentatus during the first phases of development as well as to analyse the morphometric variations at the different stages.

\section{MATERIAL AND METHODS}

Fish larvae were collected monthly, between March 1988 and April 1990, at the Itaipu reservoir (Fig. 1) with a $0.5 \mathrm{~mm}$ mesh conic-cylindrical plankton net.

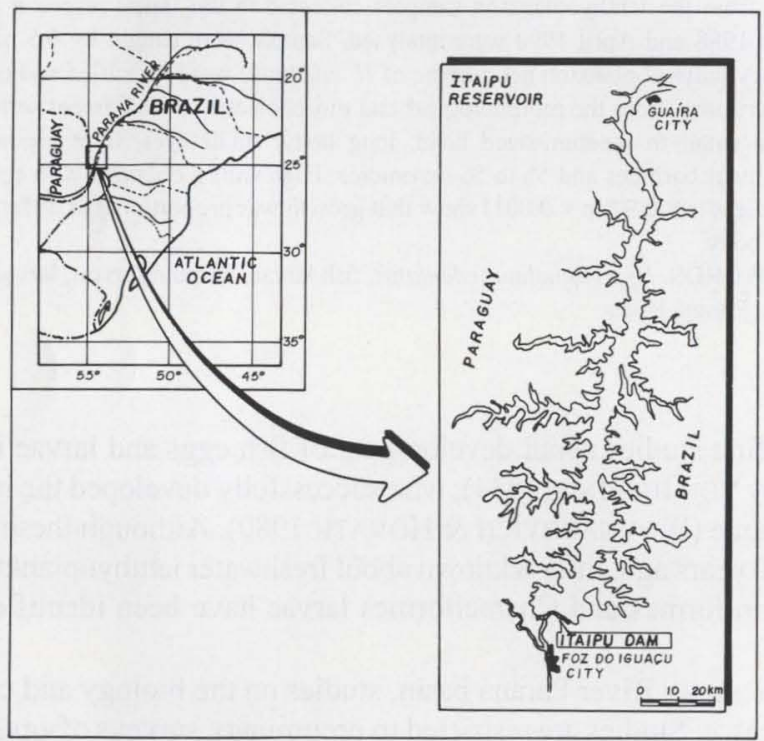

Fig. 1. Site of sampling stations.

Development series proposed by AHLSTROM \& MOSER (1976) were used for the identification of larvae. The stages of larval development were defined according to AHLSTROM \& BALL (1954) and KENDALL et al. (1984). Characteristics used for larvae identification were: shape of the body, presence of barbules, fin formation sequence, formation of fin spines and the position of the anal opening in relation to the body. On the other hand, meristic data on the vertebrae/myomeres and fin rays were also used. The clearing and staining methods used to facilitate the visualization of the structures were those suggested by POTTHOFF (1984).

The morphometry was conducted with the aid of a micrometric ocular attached to a stereoscopic microscope and the terminology defined by AHLSTROM 
et al. (1976) was used. In the morphometric analyses linear regressions were undertaken between: (a) measurements of length of head, pre-anal, pre-dorsal and height of the body in relation to standard length; (b) diameter of eye in relation to length of head. With regard to body proportions the classification of larvae was described by means of categories proposed by LEIS \& TRNSKI (1989).

\section{RESULTS}

\section{Morphological description}

Larvae of $H$. edentatus with a standard length (SL) between 4.3 and $54.0 \mathrm{~mm}$ were analysed. The morphological description of larvae of $H$. edentatus is based on specimens whose size lies between 4.70 and $16.75 \mathrm{~mm}$ (Figs 2 and 3 ) in which the different development stages of the species fit.

The $4.70 \mathrm{~mm}$ SL larva (Fig. 2A) presents an oval-shaped head at the pre-flexion phase; mouth and operculum opening are already well defined, free operculum membranes, and maxillary and mentonian barbules well developed. It is possible to observe the formation of myomeres in the body and because of transperancy the notochord. The dorsal, caudal and anal regions are surrounded by a transparent membrane (embryonic fin). At this stage the dorsal and anal fins could not be seen, whilst the caudal fin is at the initial phase of formation. The eyes with little pigmentation are evident. Anus is well defined and the intestine is relatively short with few folds. No pigmentation was observed on the body at this developmental phase.

The $8.20 \mathrm{~mm}$ SL larva (Fig. 2B) is at the flexion phase, since the terminal region of the notochord is in the flexing process. The head becomes differentiated from the body, with well-defined gill openings. In the body, the segmentation becomes quite evident, with approximately 55 myomeres; notochord is still visible. The embryonic fin is present in the dorsal and ventral regions; however, in the caudal region it is being substituted by the fin rays, although still in formation. In the ventral region the structure that will later give rise to anal fin rays is observed; but there is no sign of the pelvic fin. The pectoral fin is at the initial phase of ray formation. The eyes are pigmented and very evident. There is an increase in the intestinal folds. No pigmentation pattern in the body can be seen at this stage of development.

The $9.25 \mathrm{~mm}$ SL larva (Fig. 2C) is in the post-flexion phase with the terminal region of the notochord flexed and the supporting elements of the caudal fin already formed. The shape of the body has not changed in relation to the preceding stage. The transparent membrane of the dorsal region is slightly reduced in the anterior part, and a small protuberance appears where the rays of the dorsal fin will originate. In the posterior region the outline in which the adipose fin will originate can be seen. The caudal fin still does not have the complete number of rays. In the ventral region, the transparent membrane remains as in the preceding stage, however, the supporting structure of the anal fin rays becomes evident. The pelvic fin is still absent, and the pectoral fin becomes more evident with the ray formation. The mouth is in a terminal position, with a series of small teeth visible on the maxillas. There is an increase in the intestinal folds in relation to the preceding stage. 


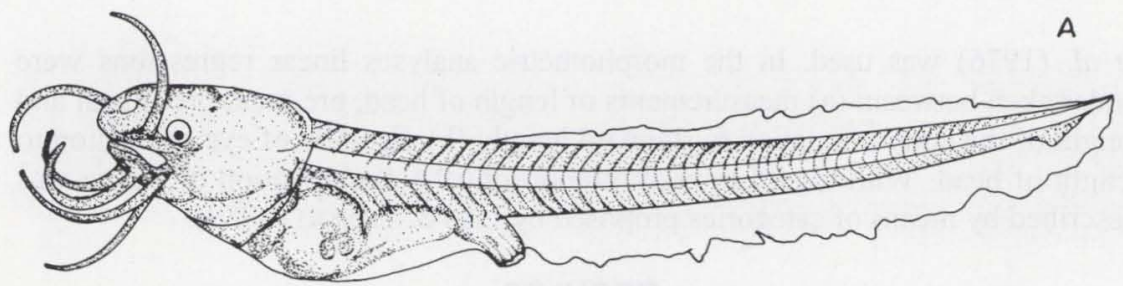

$1 \mathrm{~m} \mathrm{~m}$
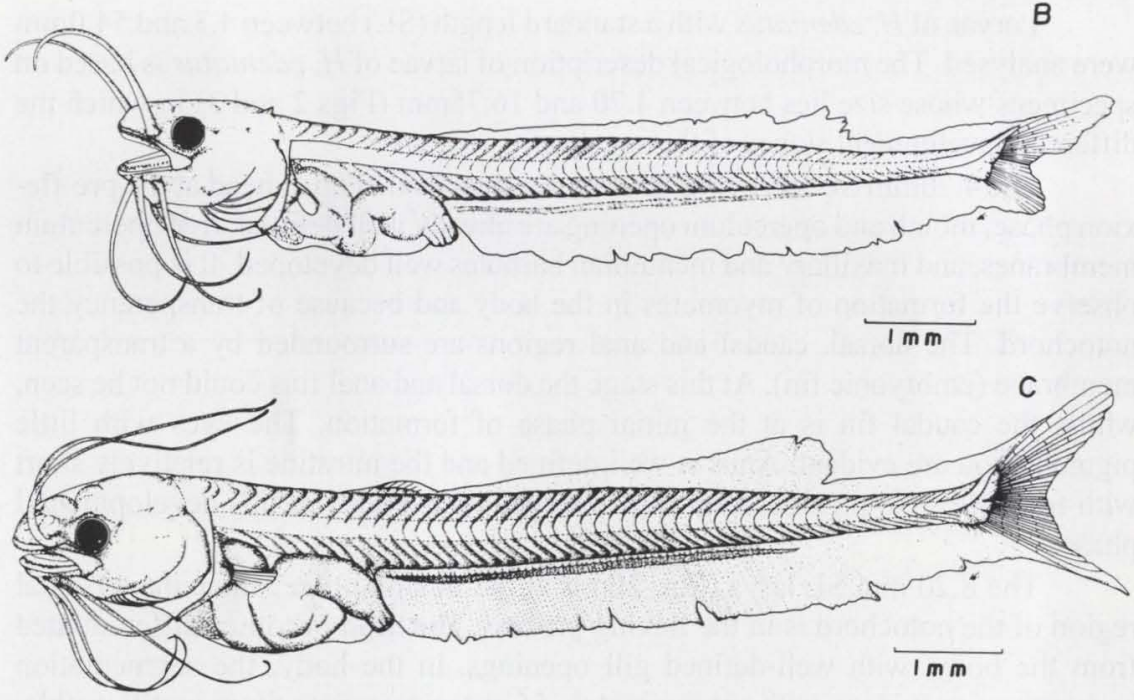

Fig. 2. Larvae of Hypophthalmus edentatus, with standard length (SL) of: (A) $4.70 \mathrm{~mm}$ (pre-flexion); (B) $8.20 \mathrm{~mm}$ (flexion); (C) $9.25 \mathrm{~mm} \mathrm{SL} \mathrm{(post-flexion).}$

The $11.75 \mathrm{~mm}$ SL larva (Fig. 3A) is in the final post-flexion phase, when the caudal fin has the complete number of rays. Seven rays are now evident in the dorsal fin. The posterior part of this fin is still covered by the transparent membrane; however, it begins to undergo a pronounced differentiation to form the adipose fin. The anal fin begins its formation from the anus towards the tail, substituting the embryonic fin, where it is possible to count about 60 rays. The pelvic fin has not appeared yet and the pectoral fin is completely formed, with an ossified and serrated spine on the first ray. In the pre-operculum small spines emerge, and the barbules become proportionally long in relation to the body. At this phase it is possible to observe sparse pigmentation over the head and along the body between the myomeres.

The juvenile individual of $16.75 \mathrm{~mm}$ SL (Fig. 3B) presents completely formed fin rays. The shape of the body has all the characteristics of an adult and practically all the morphological and meristic structures are consolidated. The number of myomeres is from 53 to 56 (Fig. 4). The dorsal fin differentiates itself 
A
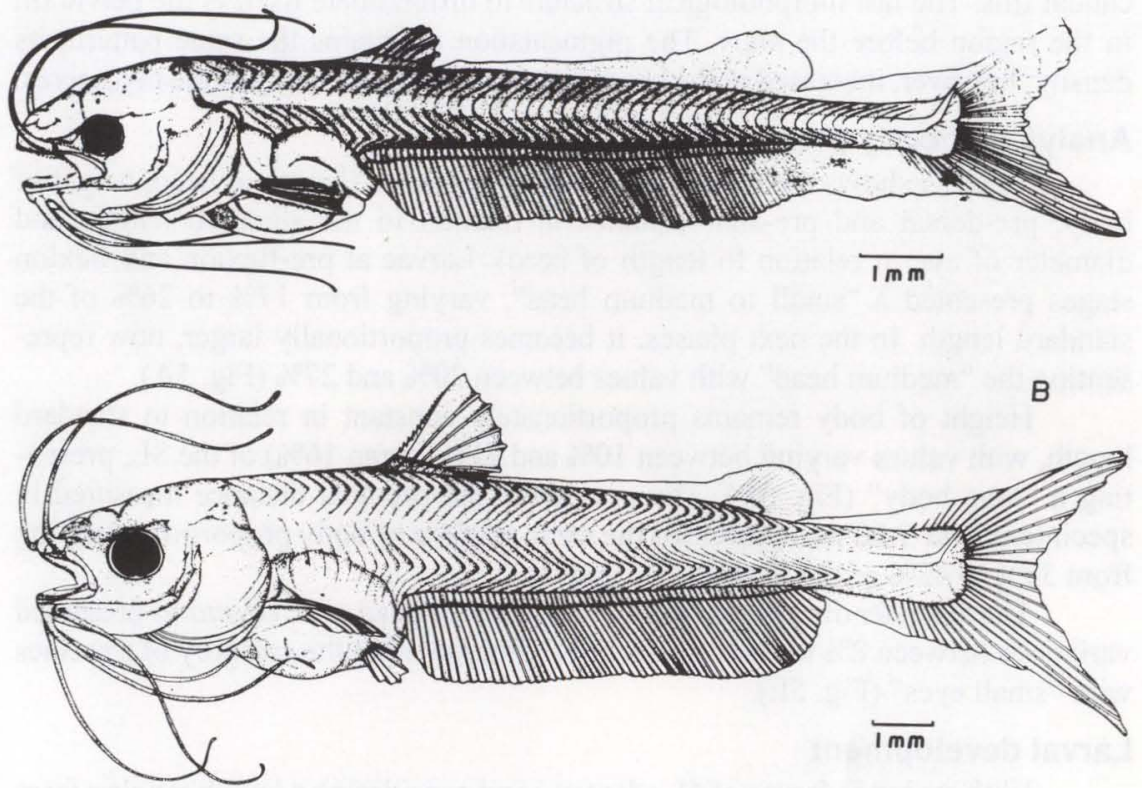

Fig. 3. Larvae of Hypophthalmus edentatus, with standard length (SL) of: (A) $11.75 \mathrm{~mm}$ (post-flexion); (B) $16.75 \mathrm{~mm}$ (juvenile).

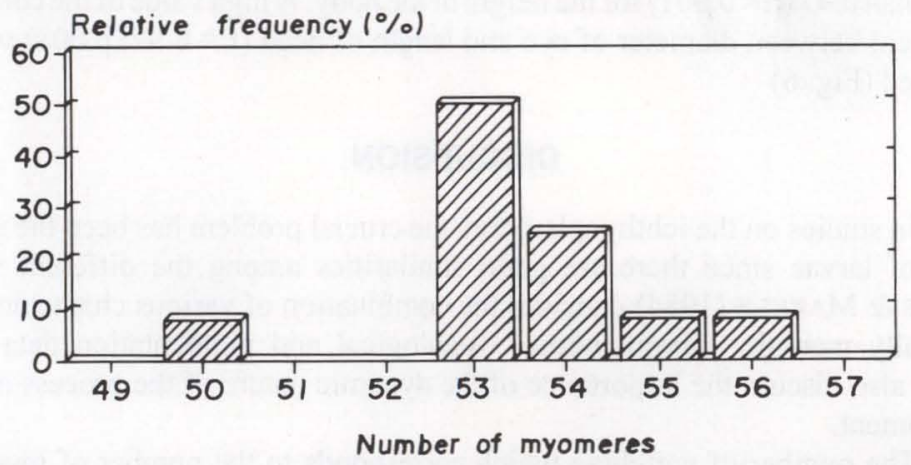

Fig. 4. Relative frequency of larvae of Hypophthalmus edentatus according to number of myomeres.

from the anterior region by presenting an ossified and serrated spine on the first ray, similar to the one found on the pectoral fin in the preceding stage. The mouth in the anterior position, maintains small denticles in the upper and lower maxilla, while the pre-operculum still presents the spines mentioned in the preceding stage. These characteristics disappear in the adult phase. The caudal, anal and pectoral fins are formed with the complete number of rays. The adipose fin is already formed too and the transparent membrane is limited to a small section between the dorsal and 
caudal fins. The last morphological structure to differentiate itself is the pelvic fin in the region before the anus. The pigmentation maintains the same pattern; its density, however, increased in the head region and along the body in the myomeres.

\section{Analysis of body proportions}

Figure 5 shows the variation in body proportions (length of head, height of body, pre-dorsal and pre-anal distance in relation to the standard length, and diameter of eye in relation to length of head). Larvae at pre-flexion and flexion stages presented a "small to medium head", varying from $17 \%$ to $26 \%$ of the standard length. In the next phases, it becomes proportionally larger, now representing the "medium head" with values between $20 \%$ and $27 \%$ (Fig. 5A).

Height of body remains proportionately constant in relation to standard length, with values varying between $10 \%$ and $21 \%$ (mean $16 \%$ ) of the SL, presenting a "long body" (Fig. 5B). The pre-dorsal and pre-anal distance measured in specimens over $9.00 \mathrm{~mm}$ presented the same patterns of body proportions, varying from $35 \%$ to $42 \%$ of the SL (Fig. 5 C and D).

The diameter of eye in relation to height of the head of H. edentatus presented variations between $8 \%$ to $26 \%$ (mean $20 \%$ ), fitting within the category of a species with "small eyes" (Fig. 5E).

\section{Larval development}

With regard to larvae of $H$. edentatus and considering a length ranging from 4.3 to $54.0 \mathrm{~mm}$, the values of the linear correlation coefficient were higher than 0.98 $(p<0.001)$ for the length of the head, pre-dorsal distance and pre-anal distance and higher than $0.97(p<0.001)$ for the height of the body. A high value of the correlation coefficient between diameter of eye and length of head $(r=0.97 ; p .001)$ was also registered (Fig. 6)

\section{DISCUSSION}

In studies on the ichthyoplankton, the crucial problem has been the identification of larvae since there are great similarities among the different species. POWLES \& MARKLE (1984) consider the combination of various characters, using principally meristic, morphometric, osteological and pigmentation data. These authors also discuss the importance of the dynamic nature of the process of larval development.

The number of vertebrae which corresponds to the number of myomeres, constitutes a basic meristic character used in the identification of larvae (DUNN 1983). ARAÚJo-Lima \& DONALD (1988) observed that, despite the limitations caused by the overlapping of the number of myomeres, this characteristic is useful in the identification of Characiformes larvae in the Amazon river. In the case of the Hypophthalmidae, HowES (1983) found an exceptionally large number of vertebrae (62) that included the vertebral complex (7). Since there is no other similar data for Siluroidei, he suggests that this group is probably monophyletic, based on these anatomical structures. However, the morphological similarities between Hypophthalmidae and species of other families, like the Ageneiosidae (49-50 vertebrae) and Auchenipteridae ( 45 vertebrae), were interpreted as being an adaptive conver- 
gence, with no osteological support that may unite these families. Since the larvae of $H$. edentatus could be confused with those of Auchenipterus nuchalis, due to their morphological similarity, the safest differentiation characteristic between the two species was the number of myomeres: H. edentatus presents 53 to 56 myomeres and A. nuchalis, 45 .
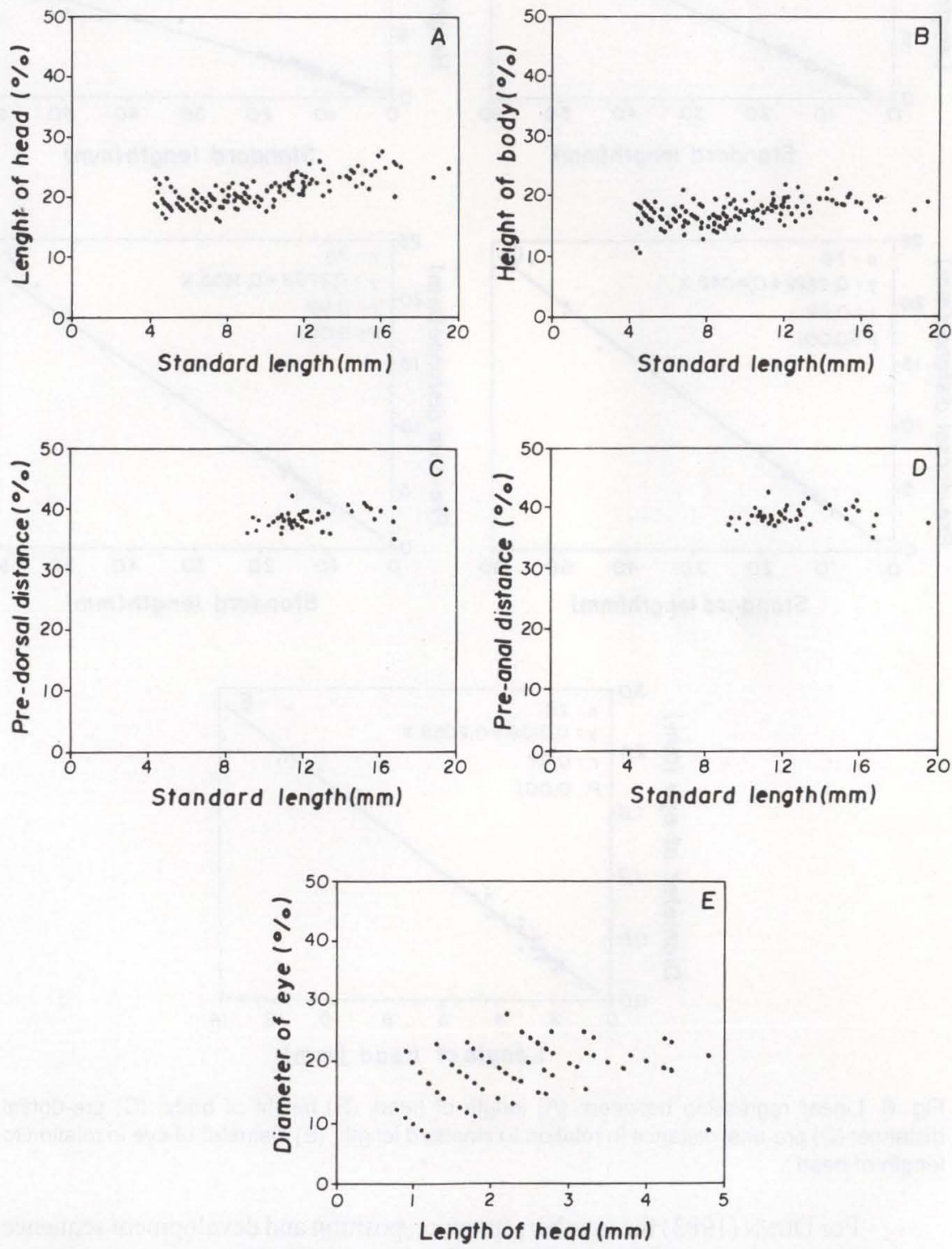

Fig. 5. Body proportions between: (A) length of head; $B$ ) height of body; (C) pre-dorsal distance; (D) pre-anal distance, in relation to standard length; $(E)$ diameter of the in relation to length of head. 

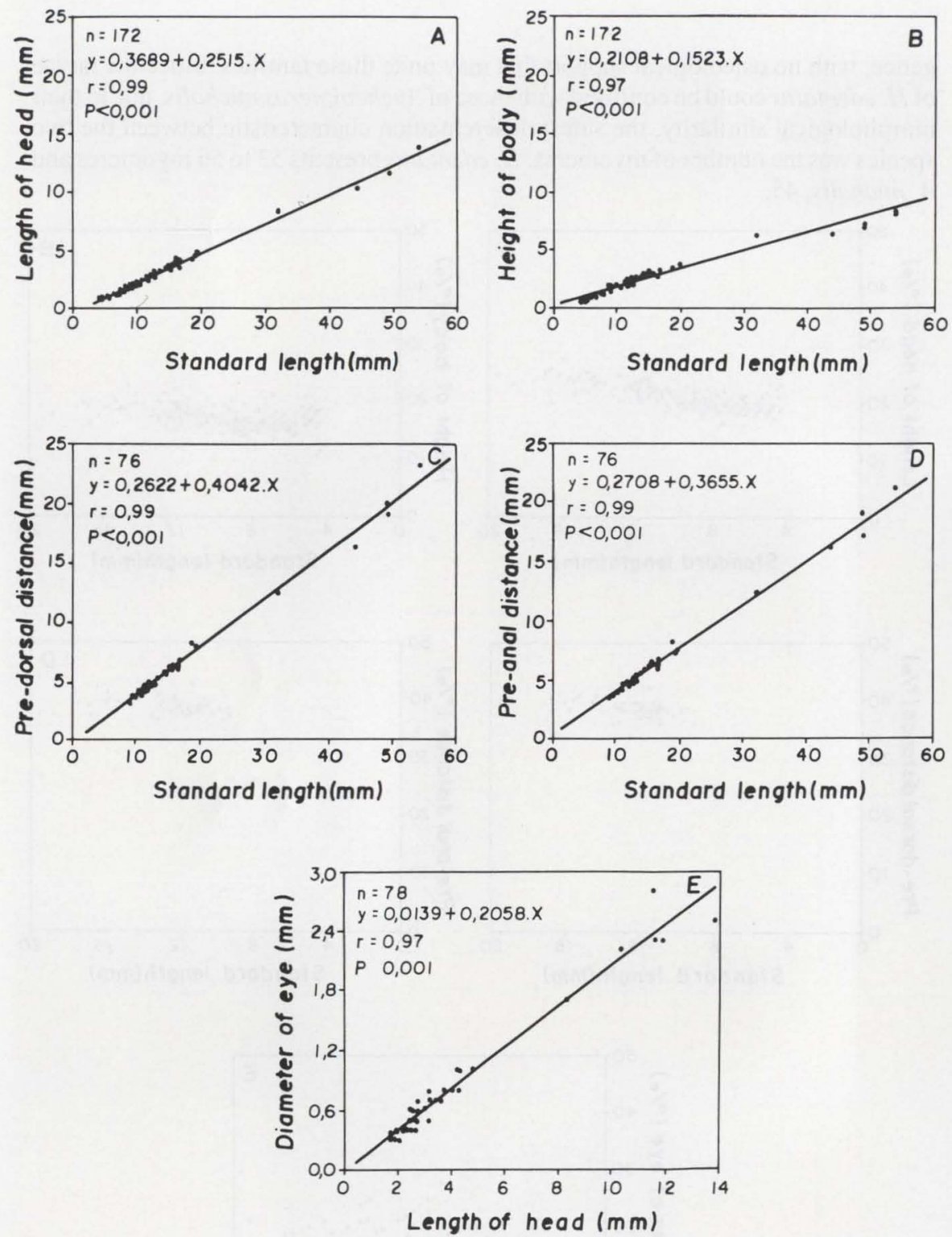

Fig. 6. Linear regression between: (A) length of head; $(B)$ height of body; (C) pre-dorsal distance; (D) pre-anal distance in relation to standard length; $(E)$ diameter of eye in relation to length of head.

For DUNN (1983) the number, structure, position and development sequence of the fins are also useful in identifying the larvae of fish. However, according to this author, the pectoral fins have less value in the identification of the larvae due to the delay in their formation. Nevertheless, this specific fin seems to be important 
for the identification of larvae of $H$. edentatus, since it presents ossified and serrated spines in the larval phase. The latter disappear completely in the adult phase and remain simply as soft rays.

The development of fish larvae is relatively fast in the first stages of their life cycle. In his studies on Parauchenipterus galeatus (Linnaeus, 1766) (=Trachycorystes galeatus) (Auchenipteridae) CHACON (1975) states that a larva measure $6.5 \mathrm{~mm}$ after three hours of life reaches $34 \mathrm{~mm}$ in 20 days.

MORAES FILHO \& SCHUBART (1955) verify that the maximum size of the larvae, soon after hatching, is $4.8 \mathrm{~mm}$ for Salminus maxillosus Valenciennes, 1840 (Characidae), 2.4 to $2.5 \mathrm{~mm}$ for Curimata elegans Steindachner, 1911 (Curimatidae), 2.5 to $2.6 \mathrm{~mm}$ for Astyanax bimaculatus (Linnaeus, 1758) (Characidae) and 4.3 to $5.7 \mathrm{~mm}$ for Hoplias malabaricus (Bloch, 1794) (Erythrinidae). In the present study, the smallest larvae had a standard length of $4.3 \mathrm{~mm}$; at this length the larvae practically possessed a full viteline sac. Thus, we suggest that this value is very close to the size of the larvae on hatching.

The larva of $H$. edentatus has the characteristics of Siluriforms: medium-sized to small head and a long body in relation to the standard length, little pigmentation, mandibular barbules and myomeres varying from 53 to 56 . The eyes in a ventro-lateral position are small in relation to the head. Variation in the diameter of the eye is much greater than that of the species of Siluriforms with a large head.

The increase in the body measurements with regard to standard length was linear for the species analysed. Thus, progressive changes that appear in the morphometry of this species show a proportional growth between the diverse parts of the individual $(r>0.97 ; \mathrm{p}<0.001)$.

ACKNOWLEDGMENTS. The authors wish to thank Dr. Angelo Antonio Agostinho, Dr. Sidney Magela Thomaz, Msc. Cláudia Costa Bonecker and Msc. Luiz Carlos Gomes for the critical review of the manuscript and for suggestions. To the biologist Kazuko Suzuki for the larvae illustrations. To the scholarship students, pupils and lab assistants of the Icthyoplankton laboratory for helping in the field work and in the laboratory. To Nupélia for its logistic support. To the Itaipu Binacional for financial and field support.

\section{REFERENCES}

Agostinho, A.A.; E. Benedito-Cecílio; L.C. Gomes \& A.A. SAmpaio. 1994. Spatial and temporal distribution of sardela, Hypophthalmus edentatus (Pisces, Siluroidei), in the area of influence of the Itaipu reservoir (Paraná, Brazil). Rev. Unimar 16 (Supl. 3): 27-40.

AHLSTROM, E.H. \& O.P. BALL. 1954. Description of eggs and larvae of jack mackerel (Trachurus symmetricus) and distribution and abundance of larvae in 1950 and 1951. Fish. Bull. U.S. 56: 209-245.

AHLSTROM, E.H. \& H.G. Moser. 1976. Eggs and larvae of fishes and their role in systematic investigations and in fisheries. Rev. Trav. Inst. Pêch. Marit. 40 (3): 379-398.

Ahlstrom, E.H.; J.L. Butler \& B.Y. SuMidA. 1976. Pelagic stromateoid fishes 
(Pisces, Perciformes) of the eastern Pacific: kinds, distributions, and early life histories and observations of five of these from the north-west Atlantic. Bull. Mar. Sci. v. 26 (3): 285-402.

ARAUJO-LIMA, C.A.R.M. \& E. DONALD. 1988. Número de vértebras de characiformes do rio Amazonas e seu uso na identificação de larvas do grupo. Acta Amazon. 18 (1-2): 351-358.

CHACON, J. DE O. 1975. Embrionic and early larval stages of "cangati catfish", Trachycorystes galeatus, Linnaeus, 1756, at the amanari fish culture station, Maranguape, Ceará, Brazil. Rev. Brasil. Biol. 35 (4): 737-744.

DUNN, J.R. 1983. The utility of development osteology in taxonomic and systematic studies of teleost larvae: a review. Washington, D.C., NOAA, Tech. Rep. NMFS Circ., 450, p.1-19.

FUEM/ITAIPU BINACIONAL. 1990. Ecologia de populações de peixes no reservatório de Itaipu, nos primeiros anos de sua formação - $7^{\mathrm{a}}$ etapa $(\mathrm{mar} / 88$ fev/89). Maringá, Fund. Univ. Est. de Maringá, Itaipu Binacional, vol. 4, 617p. HowES, G.J. 1983. Problems in catfish anatomy and phylogeny exemplified by the neotropical Hypophthalmidae (Teleostei: Siluroidei). Bull. Br. Mus. Nat. Hist. (Zool.) 45 (1): 1-39.

Kendall, A.W. JR.; E.H. Ahlstrom \& H.G. Moser. 1984. Early life history stages of fishes and their characters. Spec. Publ. Amer. Soc. Ichthyl. Herpetol. 1: $11-22$.

LEIS, J.M. \& T. TRNSKI. 1989. The larvae of Indo-Pacific shorefishes. Honolulu, Univ. Hawaii Press, 371p.

Moraes Filho, M.B. \& O. SChubarT. 1955. Contribuição ao estudo do Dourado, (Salminus maxillosus Val.) do rio Mogi Guassu (Pisces, Characidae). São Paulo, Divisão de Caça e Pesca, 131p.

NAKATANi, K.; J. LATini; G. BAUMGartneR \& M.S.T. BAUMgartner. 1993. Distribuição espacial e temporal das larvas de curvinas Plagioscion squamosissimus (Heckel, 1840) (Osteichthyes, Sciaenidae), no reservatório de Itaipu. Rev. Unimar, Maringá, 15 (Supl.): 191-209.

Powles, H. \& D.F. MARKLE. 1984. Identification of larvae, p.31-33. In: H.G. MOSER; W.J. RichARDS; D.M. COHEN; M.P. FAHAY; A.W. KENDALL JR. \& S.L. RICHARDSON (Eds). Ontogeny and systematics of fishes. La Jolla, Spec. Publ. Amer. Soc. Ichthyol. Herpetol., 760p.

PotThoff, T. 1984. Clearing and staining techniques, p.35-37. In: H.G. Moser; W.J. RichaRdS; D.M. COHEN; M.P. FAHAY; A.W. KENDALl JR. \& S.L. RICHARDSON (Eds). Ontogeny and systematics of fishes. La Jolla, Spec. Publ. Amer. Soc. Ichthyol. Herpetol., 760p.

RICHARDS, W.J. 1985. Status of the identification of the early life stages of fihes.

Bull. mar. Sci. 37 (2): 756-760.

RINGUELET, R.A.; R.A. ARAMBURU \& A.A. ARAMBURU. 1967. Los peces argentinos de agua dulce. Buenos Aires, Comis. Invest. Cient., 602p.

WOYNAROVICH, E. \& L. HOVÁRT. 1980. The artificial propagation of warm-water finfishes - a manual for extension. FAO Fish. Tech. Pap. (201): 1-183.

Recebido em 25.IV.1997; aceito em 03.VIII.1998.

Revta bras. Zool. 15 (3): 687 - 696, 1998 